\title{
A Contribution to the Study of Water-conductivity in Sycamore Wood.
}

BY

\author{
M. G. HOLMES, B.SC. \\ With thirteen Figures in the Text.
}

\begin{abstract}
THE observations which form the subject of the present paper are 1 based on an anatomical investigation of young Sycamore plants, Acer Pseudoplatamus; they have special reference to the number, size, and distribution of the water-conducting elements in the wood, considered in its transverse aspect, at intervals throughout the stem.
\end{abstract}

\section{MATERIAL.}

The work was carried out on some Sycamore saplings, collected in the dormant condition in February, 1919, the plants being from two to five years old. The lengths of these shoots are indicated diagrammatically in Fig. I. They are divided into segments, each corresponding with the growth in length during one season, and the segments are lettered $a, b, c \ldots$ from the base of the plant to its apex. Within each segment the internodes are numbered $\mathrm{I}, 2,3 \ldots$ from the base of the segment upwards. It will be seen that the specimens $\mathrm{S}_{2}$ and $\mathrm{S}_{4}$ show three years' growth, and $\mathrm{S}_{3}$ five years', the growth being continued each spring by the development of the apical bud. S5 shows two years' growth only; the bud at the apex of the main stem, $\alpha$, failed to develop in 1918 , and the laterals reached a considerable length; these are lettered $b, c, d \ldots$ The development of branches from the buds formed in the axils of the pairs of leaves at the nodes is more vigorous in the upper part of the segment, and as a rule the shoot formed from the apical bud is by far the strongest of its season. These specimens are comparable in length with the stool shoots of Hazel and Ash, previously described ( 6 and 7$)$, but the latter were of one season's growth only, and investigation was confined to wood of the first year. The Sycamore specimens show a comparatively short growth in length to have taken place during one season, with comparatively few nodes, and in dealing with them it has been necessary to take into account wood of several years.

[Annals of Botany, Vo1. XXXV. No. CXXXVIII. April, 1921.] 


\section{ANATOMY.}

In a transverse section of the internode of the Sycamore stem, the wood has a fairly uniform appearance. At the edge of the pith, characteristically six-sided in shape, are six conspicuous leaf-trace bundles, containing

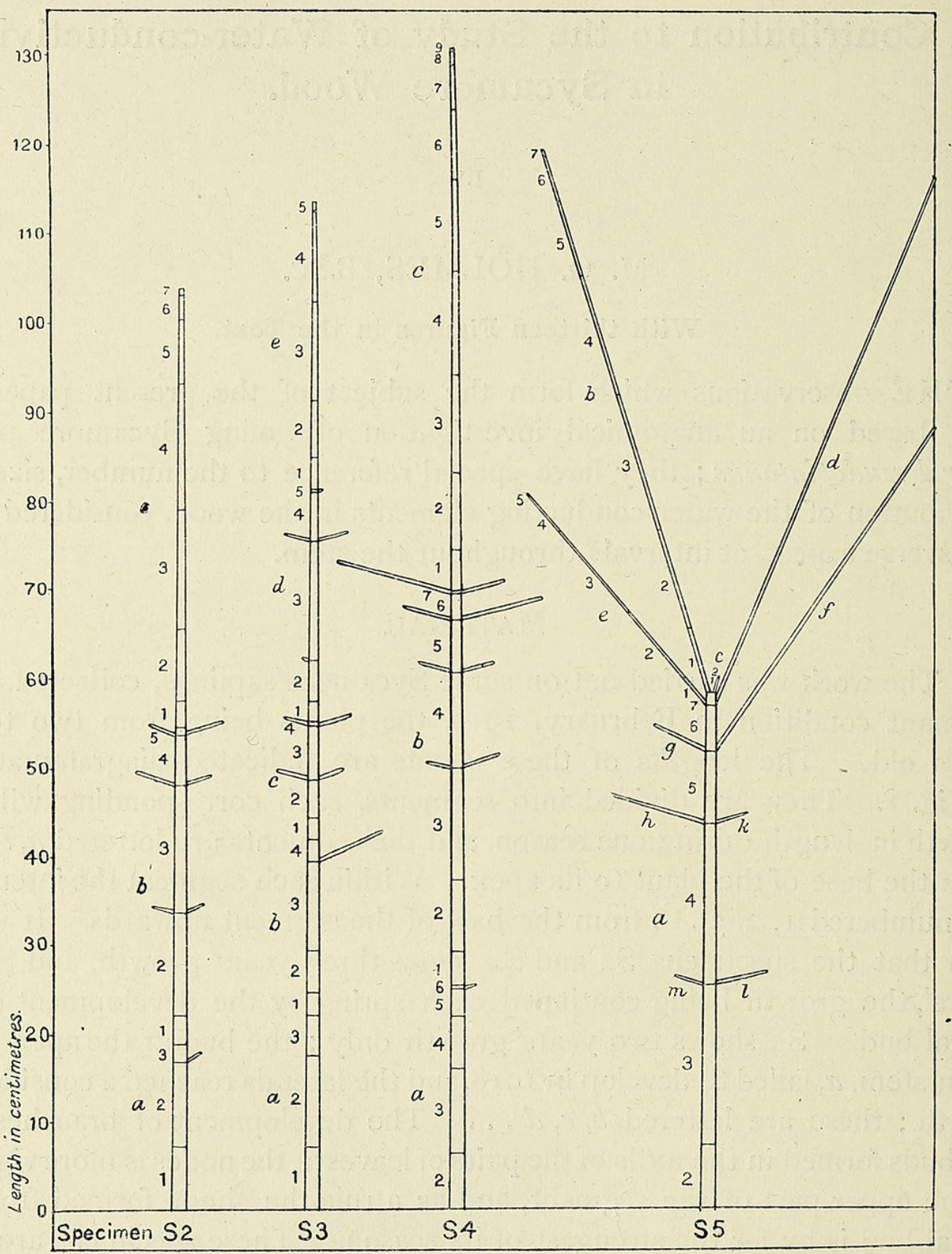

FIG. I.

spiral vessels, with smaller bundles between these. The bundles consist of several rows of vessels close together, separated from the thin-walled empty pith cells by a layer of thicker-walled parenchyma filled with starch. In the smallest sections there is little else in the xylem beyond these bundles, which are separated by medullary rays several rows of cells in width. These primary rays are distinguishable in the larger sections, traversing the 
rest of the ring of wood, with numerous smaller rays between. The typical xylem has a basis of wood fibres, interspersed fairly evenly with vessels, the tracheides and wood parenchyma being less conspicuous. Where the shoot is more than one year old the annual rings of wood are easily distinguished by the contrast in size and character between the elements on either side of

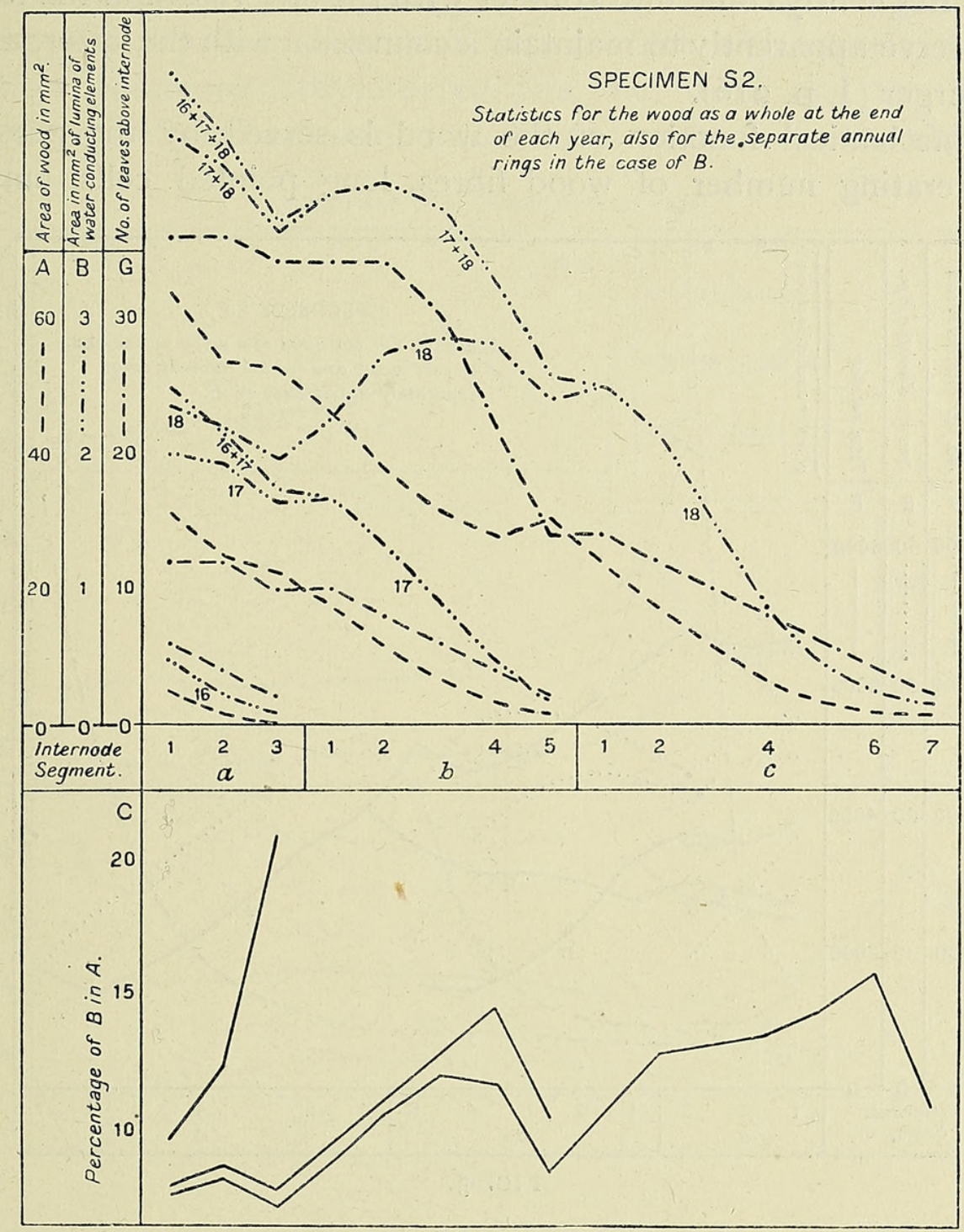

Fig. 2.

In this, and in the figures which follow, the identification-marks of the different curves will be found in the vertical columns A, B, C, \&c.

the line. The abundance of starch is a striking feature of the wood in the winter condition.

The water-conducting elements are mostly of the nature of vessels; these have short wide segments, communicating by a single large round hole in each oblique dividing wall ; the rest of the wall is thickly covered with bordered pits, and strengthened internally with fine spiral bands. Typical spiral vessels occur next to the pith, followed by somewhat transitional elements with elongated pits. Next to the outer limit of the annual ring 
there occur at intervals radial rows of smaller water-conducting elements; most of these are perforated in their end walls, but the outermost are of the nature of tracheides, very similar in shape to the wood fibres. They have pits and spiral bands as in the vessels, and are well supplied with bordered pits on their tangential walls. At the limit of the year's growth the last tracheides frequently come into contact with the first vessels of the following year, and serve apparently to maintain a connexion with the latter, as stated by Strasburger (1, p. 2I6).

The mechanical function of the wood is served by the presence of a preponderating number of wood fibres, long pointed cells, empty, the

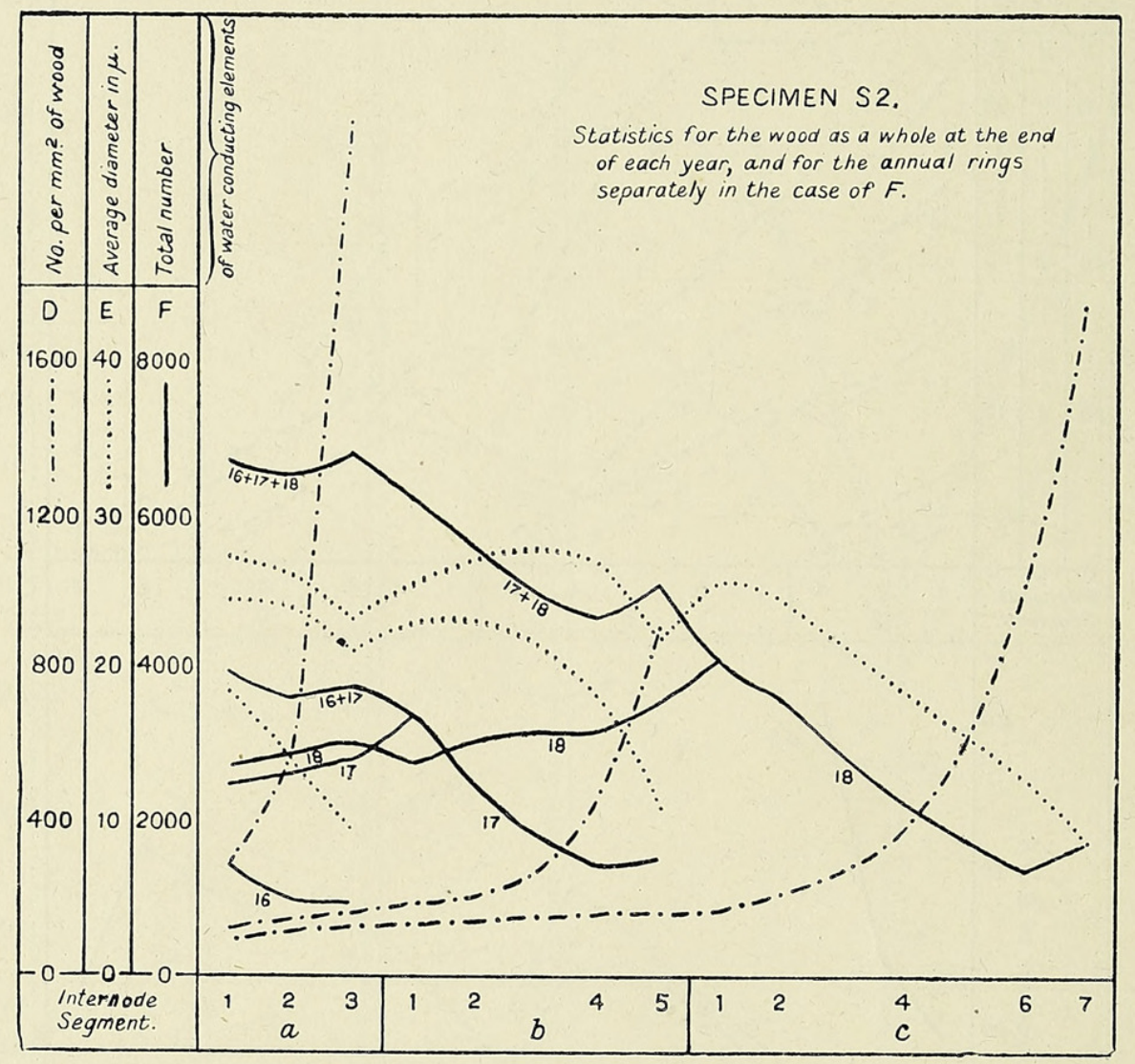

FIG. 3 .

walls sparingly supplied with simple oblique pits. Surrounding each vessel is a zone of greater or less extent consisting of cells filled with starch grains, but otherwise closely resembling the empty fibres, as seen in both transverse and longitudinal section. They have simple oblique pits, chiefly on the radial walls, and their walls may be slightly thicker and more lignified than those of the neighbouring fibres. Strasburger (1, p. 2I 5) distinguishes these elements as dead and living wood fibres. At the end of each annual ring there is a layer, several cells deep, between the rays consisting almost entirely of living, starch-bearing fibres, and radial rows of vessels and tracheides. The cells decrease in size outwards in each annual ring, and become thicker walled and flattened towards this limit, which 
is thus easily identified. Most of the starch, apart from that in the ray cells, is stored in these prosenchymatous elements, and wood parenchyma is only sparingly developed, rows of shorter, more abundantly pitted, starchbearing cells occurring occasionally near the vessels and among the flattened cells of the outer part of the annual ring. The rays, from one to six cells wide, may be anything up to forty cells high $(1$, p. 2I 7$)$; where ray or wood parenchyma cells come into contact with vessels, the dividing walls have numerous half-bordered pits, and these and the living wood fibres evidently form one continuous storage system. In the oldest parts of

SPECIMEN S3. Separate annual rings.

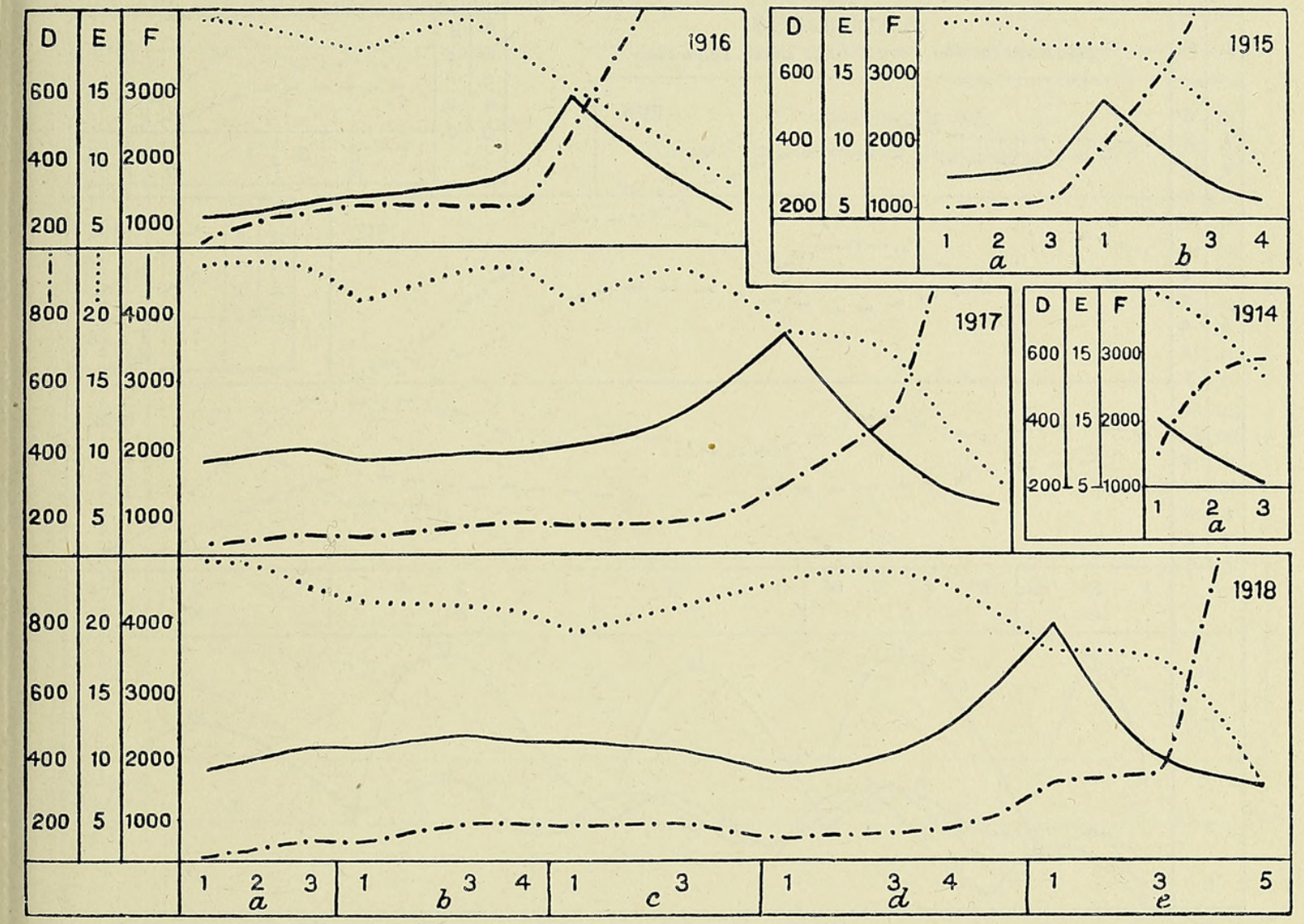

FIG. 4.

the wood examined, five years', there is abundant starch in the storage cells. According to Haberlandt $(3$, p. 684), Acer is one of the few deciduous trees which have no heart-wood; he states also that, generally, in normal circumstances, only the outermost annual rings of a shoot serve to convey the transpiration current, the more internal portions of the sap-wood serving for the storage of water and synthetic products.

The relatively small number of vessels and prevalence of fibres in Sycamore wood is mentioned by Strasburger ( 1, p. 216); and he states that the comparatively small width of the vessels, averaging about $0.035 \mathrm{~mm}$., is remarkable in view of their low proportion. Solereder $(2$, p. $27 \mathrm{I})$ also notices the small size of the vessels in Sycamore, and gives the diameter of 
the lumen as $0.06 \mathrm{~mm}$. In the present paper variation in the average diameter of the vessels for different shoots and different parts of the same shoot will be illustrated, but at this point it may be mentioned that the extreme range of individual diameter among the measurements made for these young plants is 57 to $3 \mu$.

\section{METHOD.}

In working out statistics for the size and proportion of the waterconducting elements in the wood, a method similar to that previously described for Hazel and Ash has been followed (6 and 7), the data being

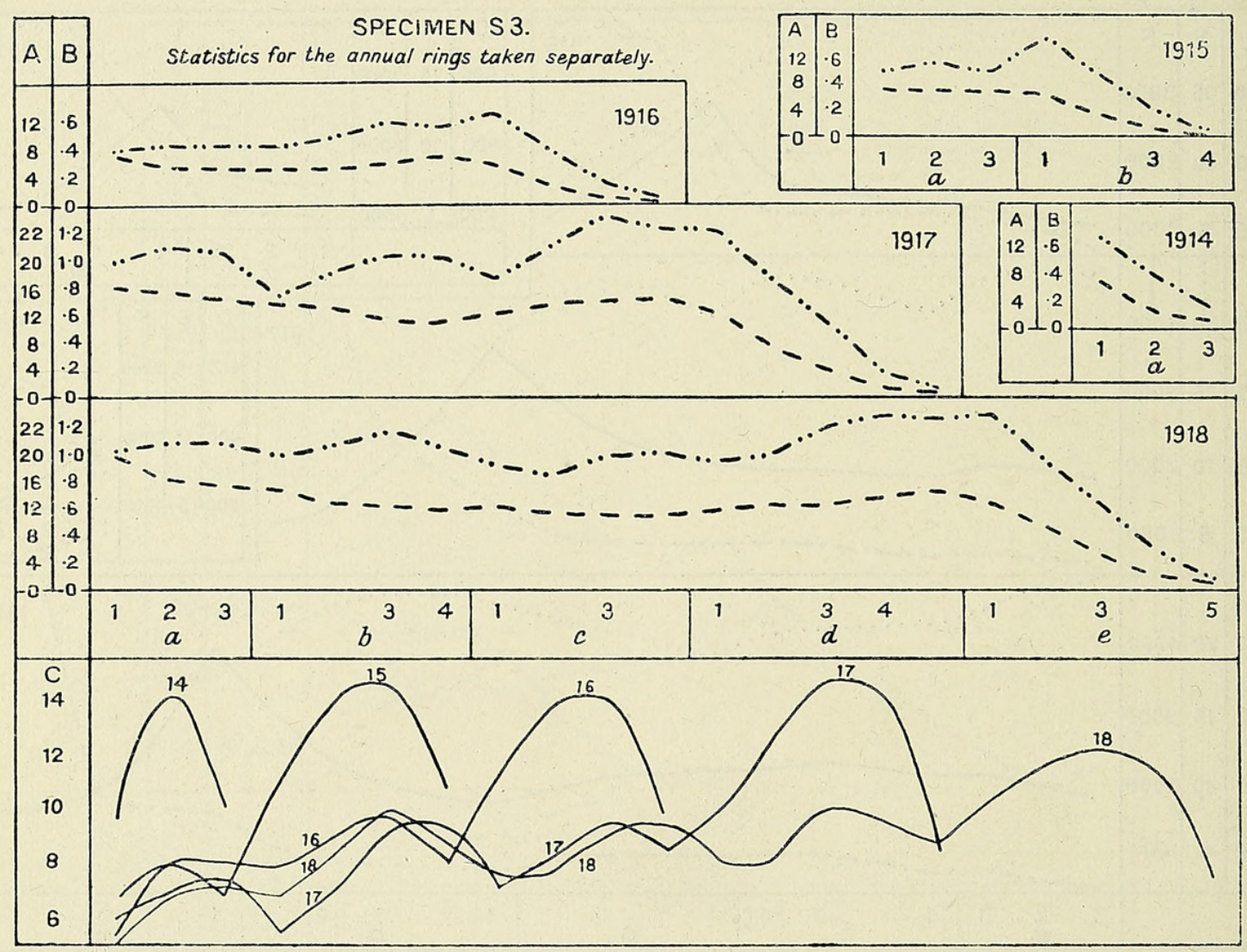

FIG. 5 .

obtained from transverse sections of the wood taken at the middle points of the selected internodes. The figures are only approximate, of course, and contain no information as to the longitudinal characters of the elements, or the resistance at the nodes. In all cases graphs were drawn from these figures to be comparable with those constructed for Hazel and Ash; the same vertical scales were taken for all, while the horizontal scale for the Sycamore is the same as that for the Ash, and double that for the Hazel, to correspond with the number of leaves borne at each node.

Here it is necessary to explain that a mistake appears in the results given in the Hazel and Ash papers, which the writer much regrets. The figures for B were worked out on the basis of a formula in which the squaring 
was done in the wrong place, so that they are in all cases rather too low. This makes the figures for $\mathrm{C}$ also too low, but the remaining figures are not affected. Thus, while retaining a similar general shape, but not exactly the same, the curves for B and C in all the diagrams ought to be higher. The numbers given to represent the limits in variation in the values for $\mathrm{C}$ $(7$, p. 263$)$ should be as follows :

$$
\begin{array}{ll}
\text { Ash } & 2.32 \text { to } \mathbf{2} 2.25 \% \text { (instead of } \mathbf{I} .68 \text { to } 9.5 \text { ) } \\
\text { Hazel } & 4.09 \text { to } 25.4 \% \text { (instead of } 3.2 \text { to } 20.26 \text { ) }
\end{array}
$$

Further corrected figures will be given below, for comparison with those obtained for Sycamore. This correction does not, however, materially affect the general conclusions of the earlier papers. ${ }^{1}$

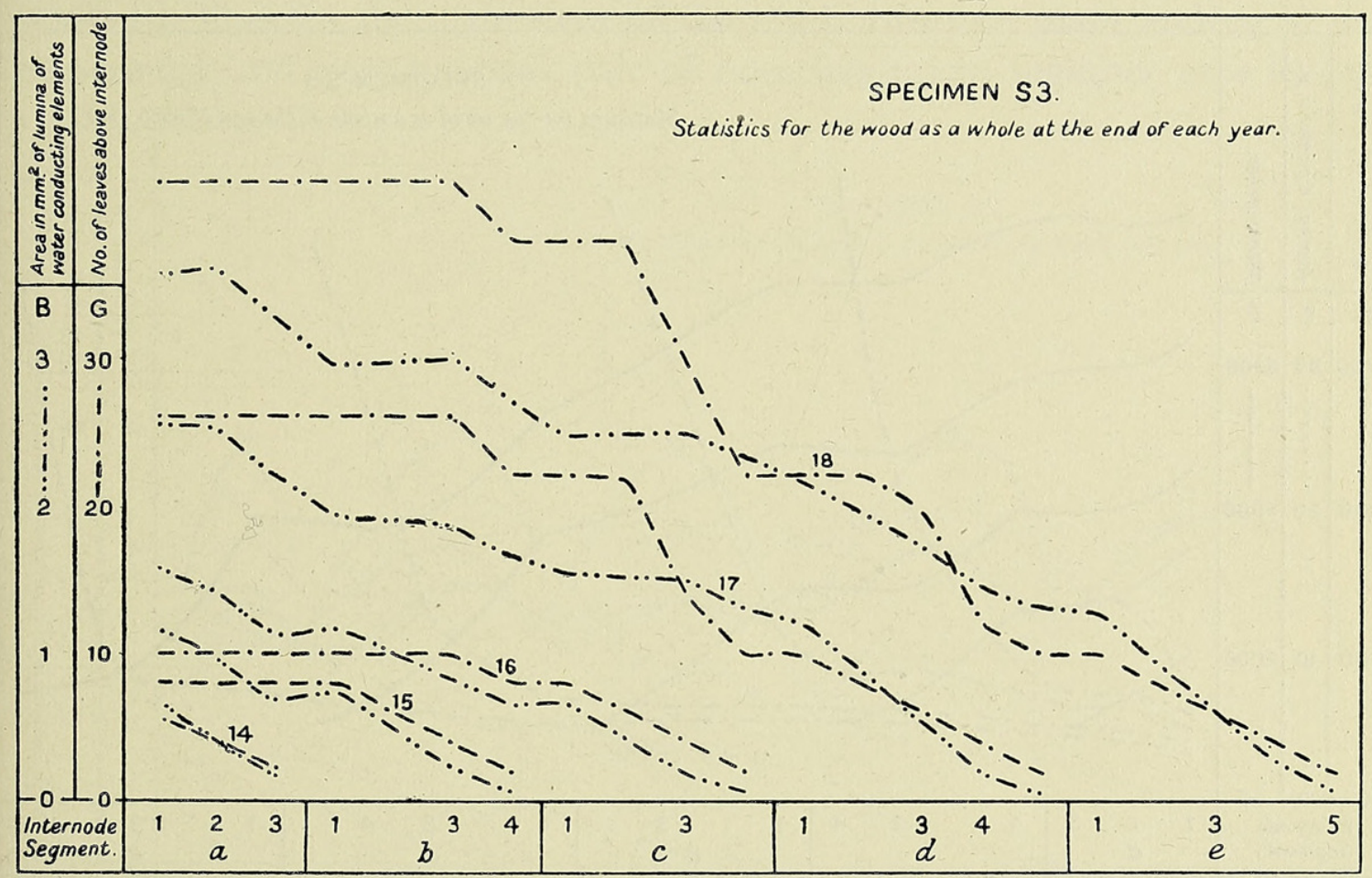

FIG. 6.

Returning to the Sycamore, it will be obvious that, when it comes to any part of the stem which is more than one year old, equal intervals on the base line do not any longer correspond with equal numbers of leaves supplied; some nodes are bare, while others have one or two lateral

1 The incorrect formula was based on the corresponding values for $E$ and $F$, as follows :

$$
B=F \times \pi\left(\frac{E}{2}\right)^{2} \div 10^{6} \mathrm{~mm}^{2}(E \text { being in } \mu \text { ). }
$$

$C$ was worked out from the value found for $B$.

The correct calculation is as follows :

Suppose that the diameters are measured at intervals of $e \mu$, and let $F=\left(f_{1}+f_{2}+f_{3}+\ldots\right)$, in which $f_{1}, f_{2}, f_{3}, \ldots$ represent the numbers of elements having diameters of $1 e, 2 e, 3 e, \ldots \mu$; then

$$
\begin{aligned}
B & =f_{1} \pi\left(\frac{e}{2}\right)^{2}+f_{2} \pi\left(\frac{2 e}{2}\right)^{2}+f_{3} \pi\left(\frac{3 e}{2}\right)^{2}+\ldots \mu^{2} \\
& =\frac{\pi e^{2}}{4 \times 10^{6}}\left(f_{1}+2^{2} f_{2}+3^{2} f_{3}+\ldots\right) m m^{2} .
\end{aligned}
$$


branches, of various lengths. This circumstance introduces irregularities into the curves, beyond those due to differences in the sizes of the leaves. About the latter no information can be given for these specimens; but to represent the number of leaves borne along the shoot during each season, another line, G, has been introduced into some of the graphs; the height of this line at the position representing each internode indicates the number of leaves on the stem above that internode.

In all cases where the stem cut was more than one year old, the data were worked out for each annual ring separately, and the figures were also combined to furnish statistics representing the condition of the wood as a whole at the end of each year's growth. From these figures it is

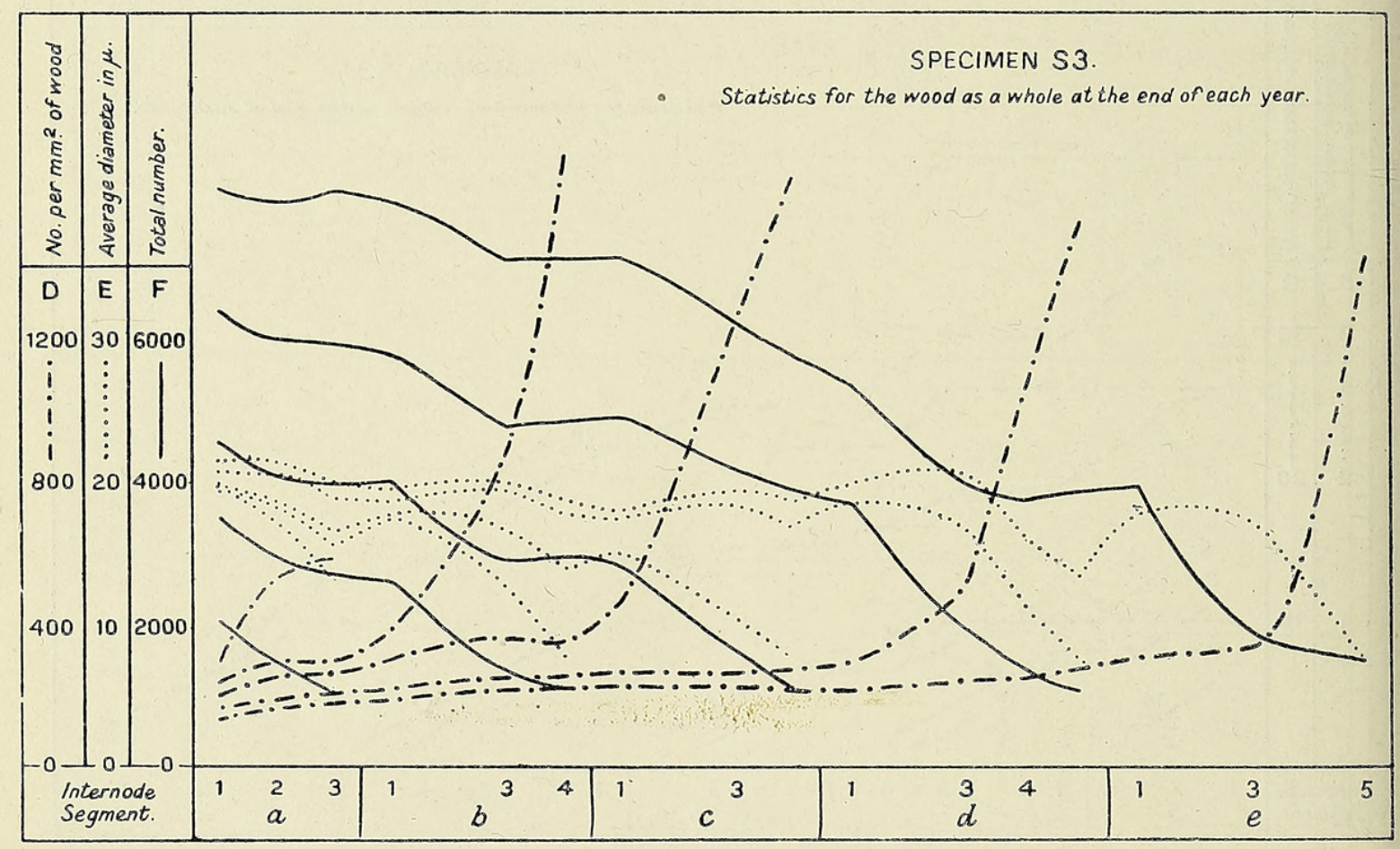

FIG. 7 .

possible to draw a line representing quantitatively the extent of development of a particular character, for a particular annual ring as far as it extends along the stem, or for the whole of the wood present at the end of a particular year. Considering the curves which come into the latter category, it is evident that those representing the areas of the wood along the same stem at the end of each year of its growth, A; or the areas of the lumina of all the water-conducting elements, B, or the numbers of these elements, F, may be drawn without interference between the same co-ordinates; this is sufficiently true in practice of the other curves also, representing specific rather than absolute data. But the curves which belong to the former category may interfere in this sense, so that separate diagrams to illustrate these have been introduced in some cases. Thus for specimen $\mathrm{S}_{3}$, which is five years old, there are five lines for each of the seven 
characters $A$ to $G$, in each category; the thirty lines $A$ to $F$ of the first category are set out in Figs. 4 and 5, while the thirty-five lines A to G of the second group appear in Figs. 6, 7, and 8. There is, of course, only one set of $\mathrm{G}$ lines, and each pair of corresponding lines from the two groups has a common ending in the one-year part of its course. In the cases of $\mathrm{S}_{2}$ and $\mathrm{S}_{4}$, each three-year-old specimens, the twenty-one lines have been drawn for the wood as a whole at the end of each year, in Figs. 2 and 3, and Figs. 9 and I0. The other lines are not given, except for $\mathrm{B}$ and $\mathrm{F}$, and these additional portions, giving values for the annual rings taken separately, are inserted into the same diagrams for comparison. In the case of $\mathrm{S}_{5}$, the statistics for three of the one-year-old laterals are indicated in Fig. II, while the lines for the main stem of the whole two-year plant, ending in the uppermost, and very unequal, pair of branches taken together as a leader,

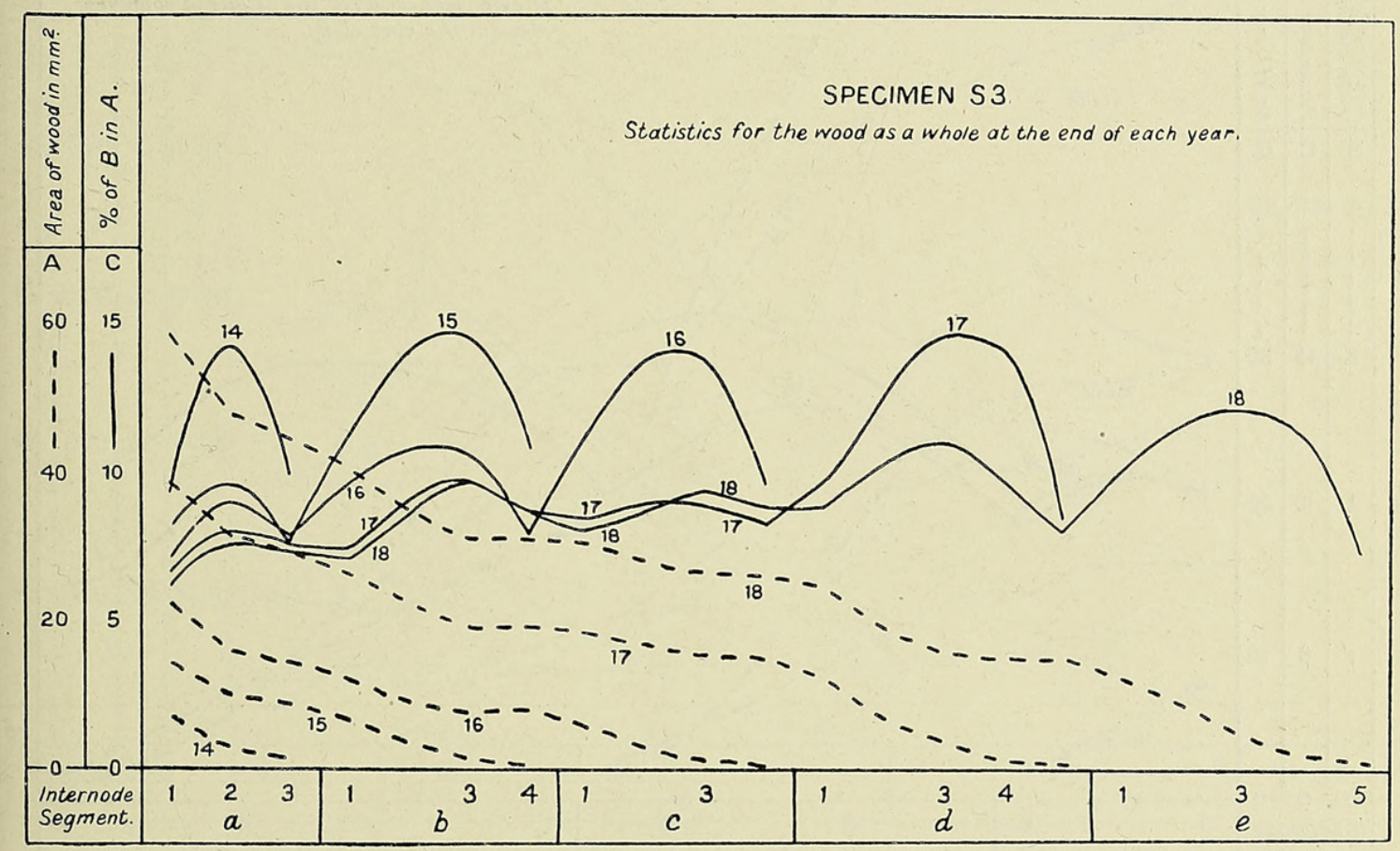

FIG. 8 .

are given in Figs. I $2_{2}$ and I $_{3}$. These include the lines of both categories; they are distinguished by the insertion of dates, the numbers referring to the years in which the wood was developed.

\section{RESULTS.}

It will be convenient, in discussing the significance of these observations, to begin with the simpler parts which have reference to first-year wood, and afterwards to consider the whole series in the two categories mentioned above.

Wood of the first year. It will be seen that a general similarity in direction exists in the curves constructed for first-year wood in the three plants. Curve A, giving in sq. $\mathrm{mm}$. the area of the wood in transverse section at the middle of each internode, shows a gradual decline from base to 
apex in each first-year segment, steeper as usual towards its beginning. It will be seen from Figs. I, 2, 5, and 10 that in $\mathrm{S}_{3}$ the annual additions to the plant were shorter and thinner than in $\mathrm{S}_{2}$ and $\mathrm{S}_{4}$. The water-conducting area in this wood is indicated in Curve $\mathrm{B}$, which gives the total area in $\mathrm{mm} .^{2}$ of the lumina of all the water-conducting elements in the transverse section of the wood at each internode. This also shows a simple decline from the base to the apex of each shoot in its first year, somewhat flatter towards the end; it corresponds to the simple successive decreases in the number of leaves supplied, the upper ones being smaller than the lower ones. The total number of the water-conducting elements in each section, as shown in

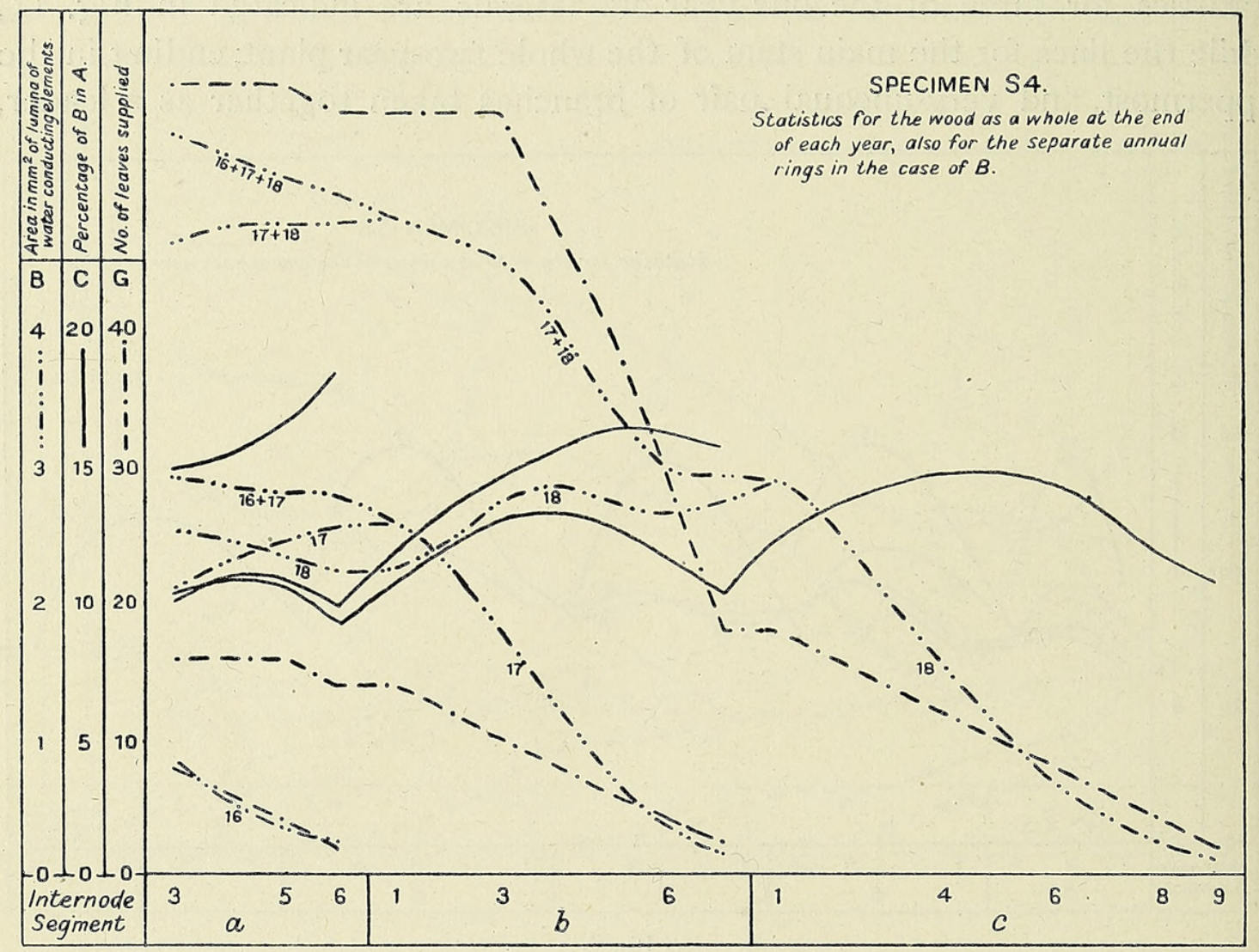

FIG. 9.

Curve $\mathrm{F}$, reveals again a decline from base to apex, but there is a tendency towards a marked flattening, or even a rise, quite close to the end, Figs. 3 , 4, Io, and II. These elements, however, are particularly small, as shown by the steeper decline of Curve $\mathrm{E}$, which gives the average diameters of their lumina in $\mu$, towards the end of each first-year shoot. The vessels of large diameter occur in the lower part of the shoot, where the average diameter falls quite slowly, while they are absent from the apical part. The distribution of the conducting elements may be inferred to some extent from Curve $D$, which shows the number occurring per square millimetre in the transverse section of the wood in each internode; the line rises gradually at first, and then with increasing rapidity towards the end in each first-year 
shoot, Figs. 3, 7, I0, and II. The shape of Curve D in Sycamore is much more like that characteristic of Hazel than that of Ash stool shoots, where the wood is particularly poor in vessels. Considering only wood of the first year, the limits of variation in the width and distribution of these elements, among the measurements made for the three plants, may be compared as follows :

\begin{tabular}{|c|c|c|c|}
\hline & Ash. & Sycamore. & Hazel. \\
\hline $\begin{array}{l}\text { Range in values of } \mathrm{E} \text { in } \mu \\
,, \quad, \text { actual diameters in } \mu \\
, \quad, \text { values for D }\end{array}$ & $\begin{array}{c}27 \cdot 85 \text { to } 10.14 \\
80,3 \\
32,, 633\end{array}$ & $\begin{array}{r}27 \cdot 85 \text { to } 7 \\
60,, 3 \\
\text { I } 37,, 2233\end{array}$ & $\begin{array}{l}23 \cdot 27 \text { to } 4 \cdot 9 \\
\text { i } 48,2 \\
\text { I I } 5,4000\end{array}$ \\
\hline
\end{tabular}

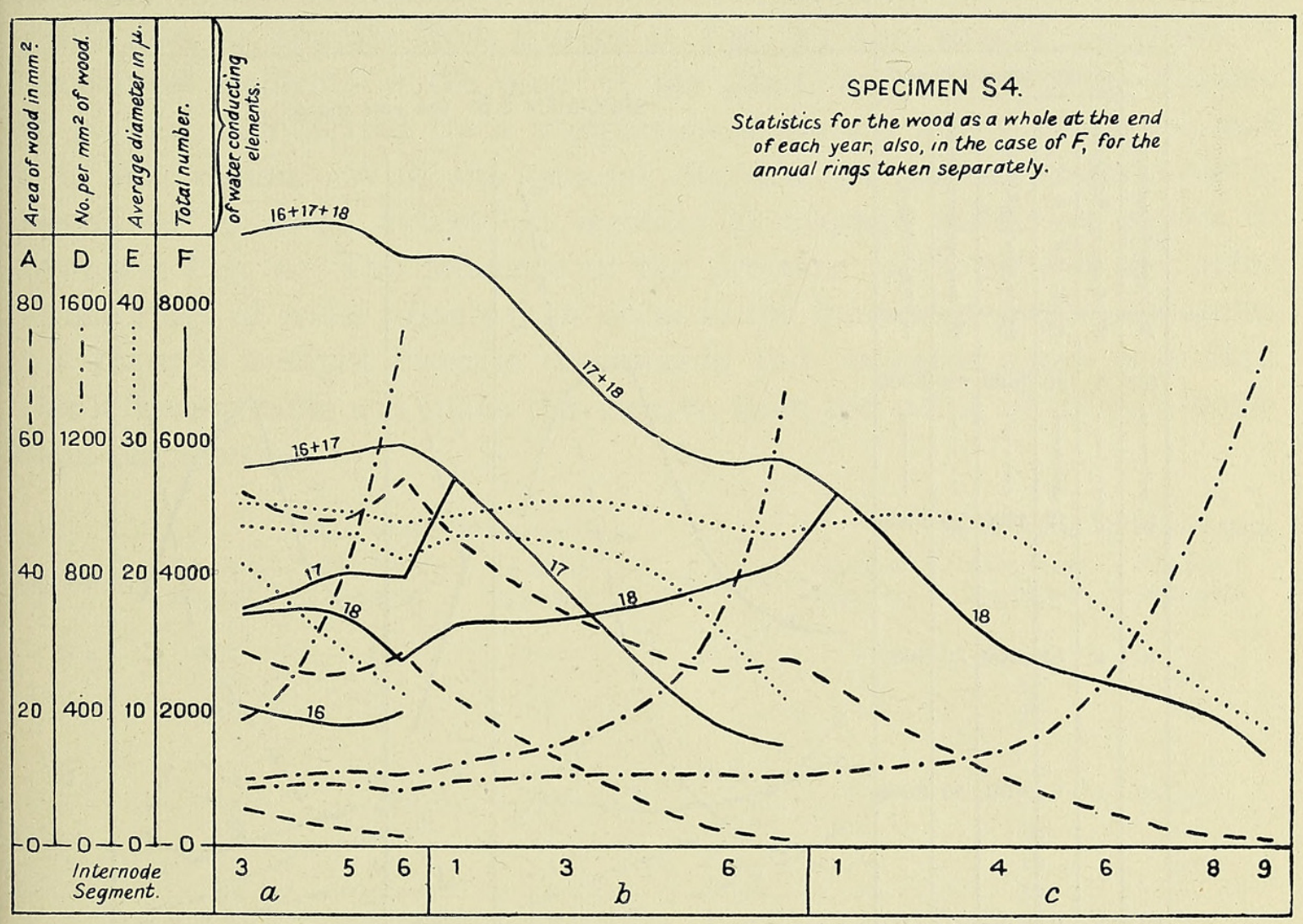

FIG. IO.

The result is that the specific conductivity for the first-year Sycamore wood, as represented by Curve $C$, which gives the percentage of B in A, is near that for Hazel, both being higher than that for Ash :

$$
\begin{array}{cccc} 
& \text { Ash. } & \text { Sycamore. } & \text { Hazel. } \\
\text { Range in values of C, \% } & 2.3^{2} \text { to } \mathbf{1 2 . 2 5} & 7.19 \text { to } 20.93 & 4.09 \text { to } 25.4
\end{array}
$$

It must be remembered that this shorter range of values for Sycamore as compared with Hazel has been obtained from shorter shoots, not altogether comparable with stool shoots. A particularly low specific conductivity at the base is characteristic of stool shoots, as mentioned by Farmer (5, p. 241). It is apparent from Figs. 2, 8, 9, II, and I2 that there is considerable variation in the shape of Curve $\mathrm{C}$, as among the different specimens, though there is a tendency to a fairly close similarity in its shape 
for the successive first-year segments of the same specimen. In general, there appears to be a similar tendency towards a rise followed by a fall, as was shown for Hazel and Ash. That is, there is a preponderance of fibrous elements towards the base of the shoot, where mechanical efficiency is most necessary, while at the apex the specific conductivity is again reduced owing to the small size of the conducting elements, in spite of their large number. Exceptions to this occurrence of rise and fall in Curve $\mathrm{C}$ for first-year shoots are shown in $S_{2}$ a, 1916, a short basal main stem, in which there is a rise only; and in $\mathrm{S}_{5} c$, a very weak lateral in which there is only a fall, cf. A8 $e$.

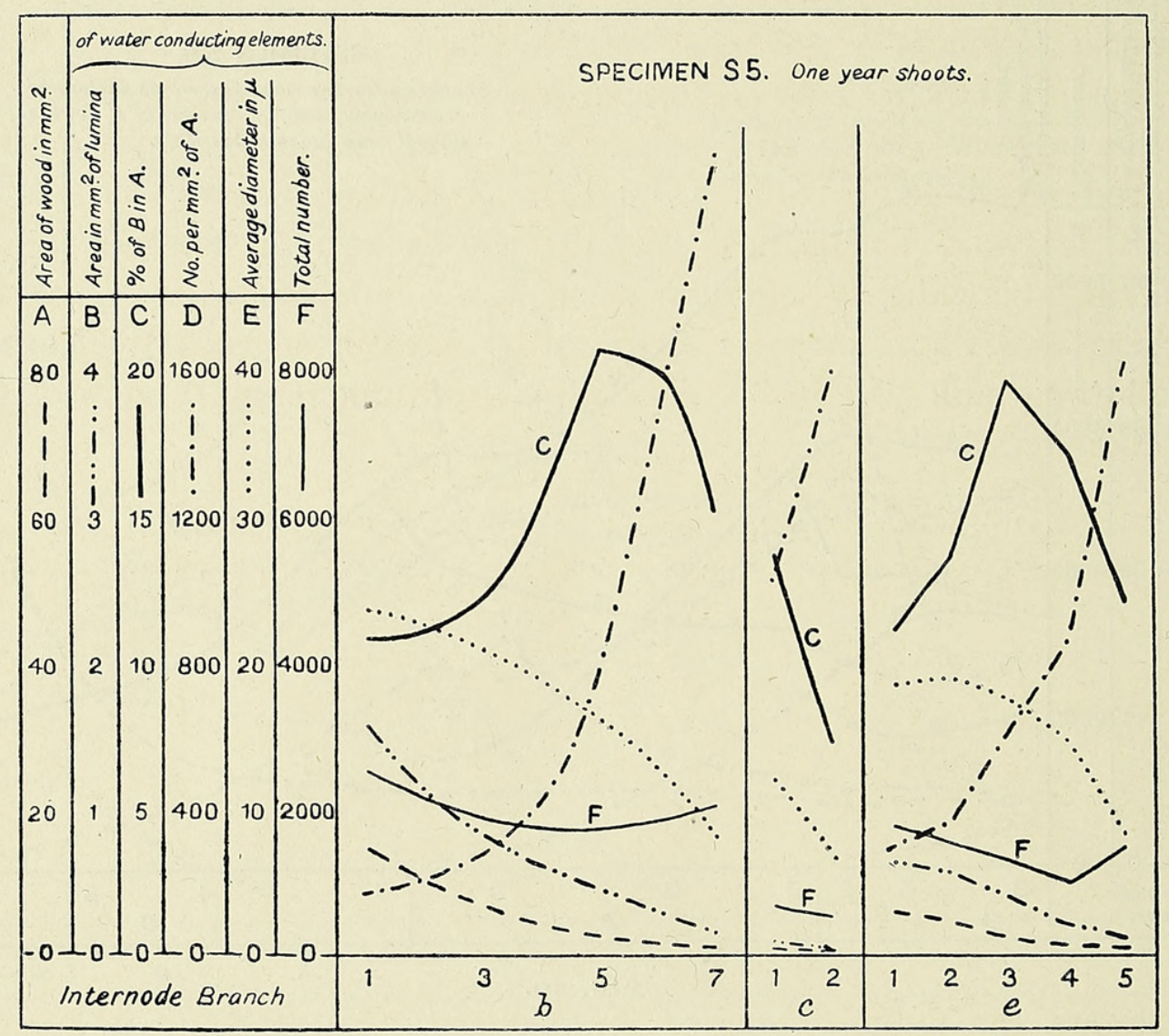

FIG. II.

Wood of the second and following years. We come now to the consideration of the character of the wood in parts of the stem more than one year old, apart from that composing the innermost annual ring. In the second and later annual rings leaf-trace bundles are absent, so that the wood has a more uniform structure; the vessels also reach a greater diameter. The differences between the wood of the first and subsequent years are illustrated in Figs. 4 and 5 , in which lines, representing the characters of each annual ring separately, are drawn for $\mathrm{S}_{3}$, the five-year-old specimen. The transverse sectional area of the wood composing each annual ring, Curve A, Fig. 5, is maintained at a fairly constant level in the internodes as its course 
is traced downwards, this level being about the same as that at the first internode of the final segment. The same condition may be inferred from Figs. 2 and Io; here the rise in the curve at the final internodes of the lower segments is due to the fact that the wood widens out at the nodes, and that these internodes are very short; see Fig. I. The size and numbers of the water-conducting elements in these annual rings are illustrated in Fig. 4. Curve $\mathrm{F}$ shows a maximum for the total number at the first internode of the final segment, and a general tendency to decrease in the number, as the curve is traced backwards. This may be seen also in Figs. 3 and 10. The number of these elements per unit area naturally tends to decrease downwards also, as appears from Curves D, Fig. 4; the special provision of mechanical elements at the base of the plant, as mentioned by Farmer (5, p. 24I), is indicated by a comparison of Curves A and D, Figs. 5 and 4 , in this region. With the general decrease in number downwards is associated to some extent an increase in average width, as shown in Curves E, Fig. 4. The influence of the presence in the second and outer annual rings of wider vessels than occur in the innermost ring is apparent, and there is a slight increase downwards and outwards apart from this. The following table will make this clearer, from the point of view of maximum diameters :

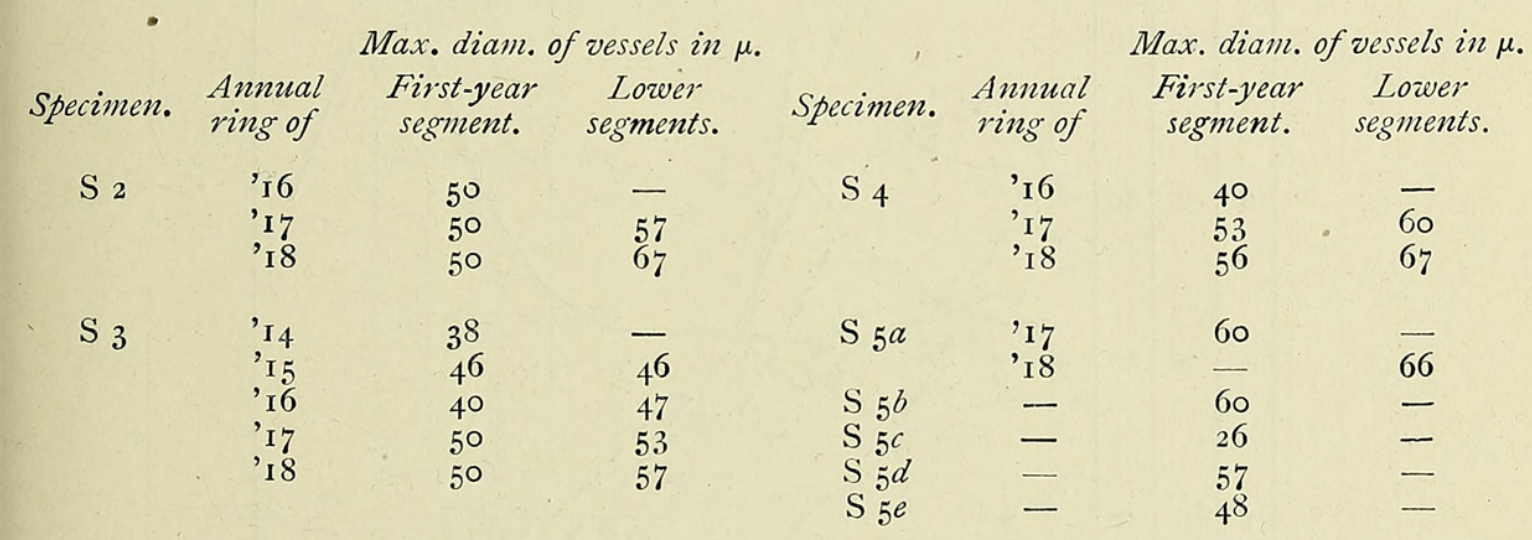

Among the figures obtained for average diameters and numbers per unit area, in wood of the second and outer rings only, taken separately, the limits of variation are as follows :

Range of values for $\mathrm{E}$ in $\mu \quad 3 \mathrm{I} \cdot 35$ to $\mathrm{I} 7 \cdot 04$

These various factors contribute to keep the conducting area, as represented by Curves B, Fig. 5, fairly level along its course in each separate annual ring, with a maximum generally at the first internode of the last segment. This appears also in Fig. 9, but is less clear in Figs. 2 and I 2. Of course Curve B represents the absolute conducting capacity in its transverse aspect only ; its fall backwards from the maximum is probably compensated, and more than compensated, by the greater length and decreased 
resistance of the wider vessels. The final result in this series, that is, the specific conductivity in its transverse aspect, is indicated in Curves C, Fig. 5. The percentage of $\mathrm{B}$ in $\mathrm{A}$ in each separate annual ring shows less variation as the line is traced backwards; there is a general tendency towards a lower specific conductivity in the lower part of the stem. It is sufficiently evident from the diagrams that the maximum values for $\mathrm{C}$ occur

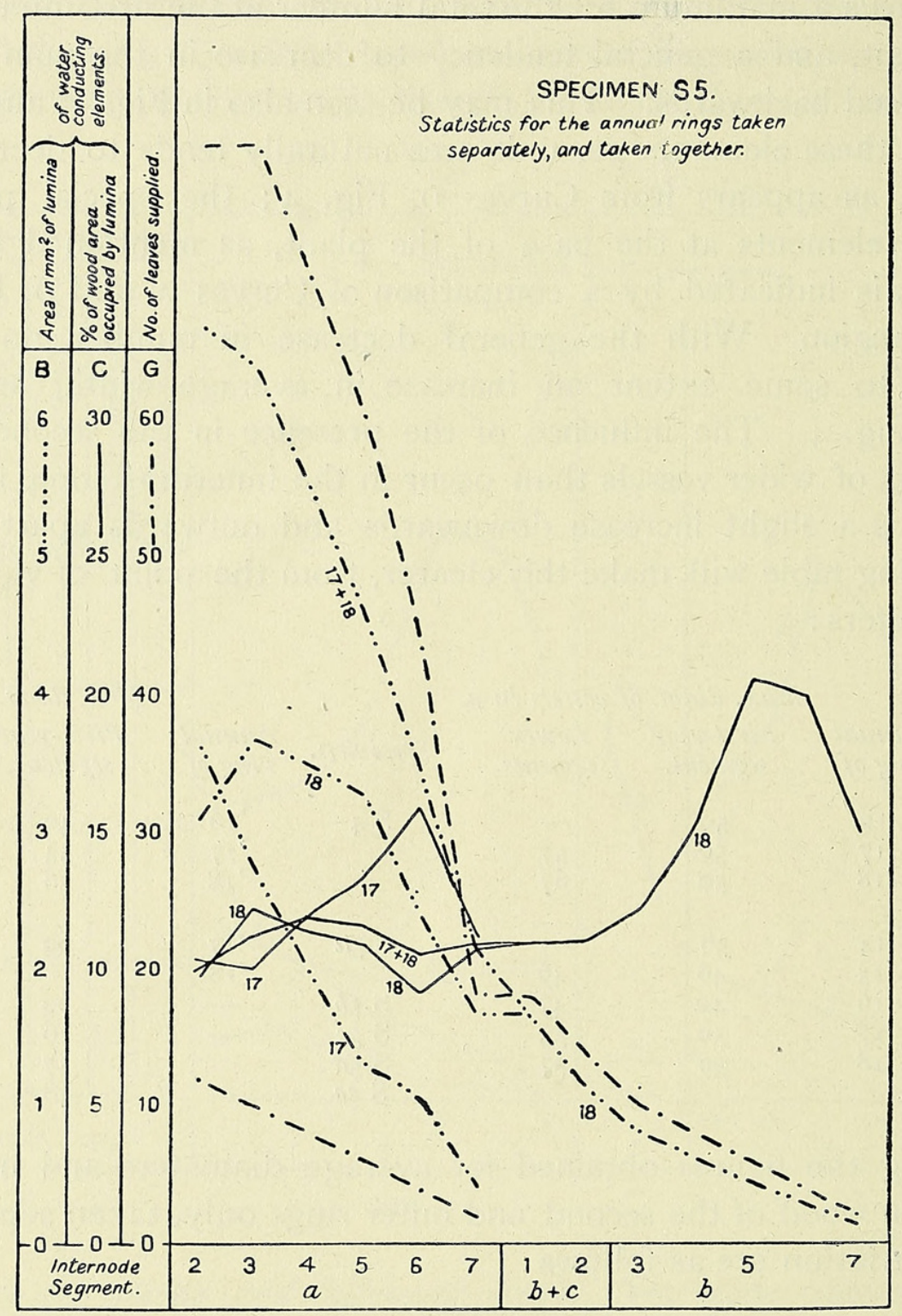

FIG. 12.

in first-year wood. The range of values observed for $\mathrm{C}$ in the wood of separate annual rings, apart from first-year wood, is 5.05 to 12.42 per cent. Statistics for the wood as a whole. Professor Farmer's figures for specific conductivity (5) for shoots of various ages are worked out on the basis of the sectional area of the whole of the wood present. With these may be compared as far as practicable the values plotted out in Figs. 2, 3, $6,7,8,9,10, I_{2}$, and $I_{3}$, to indicate the condition of each factor at the end 
of each growing season. For instance, the repetitions of Curve A in Figs. 2, 8,10 , and 13 give a sufficiently clear idea of the general effect of the yearly additions to the area of the wood. The curves are fairly smooth, apart from the local rises at the ends of segments, as noticed above. Turning to the statistics for the water-conducting elements as given in Figs. 3, 7, and Io, we find that the curves for $\mathrm{D}$ become smoother and flatter, as the influence of the first-year ood is less felt. On plotting the total numbers of these elements present in the whole of the wood, there is produced for each plant a series of descending curves, $\mathrm{F}$, in which the most con-

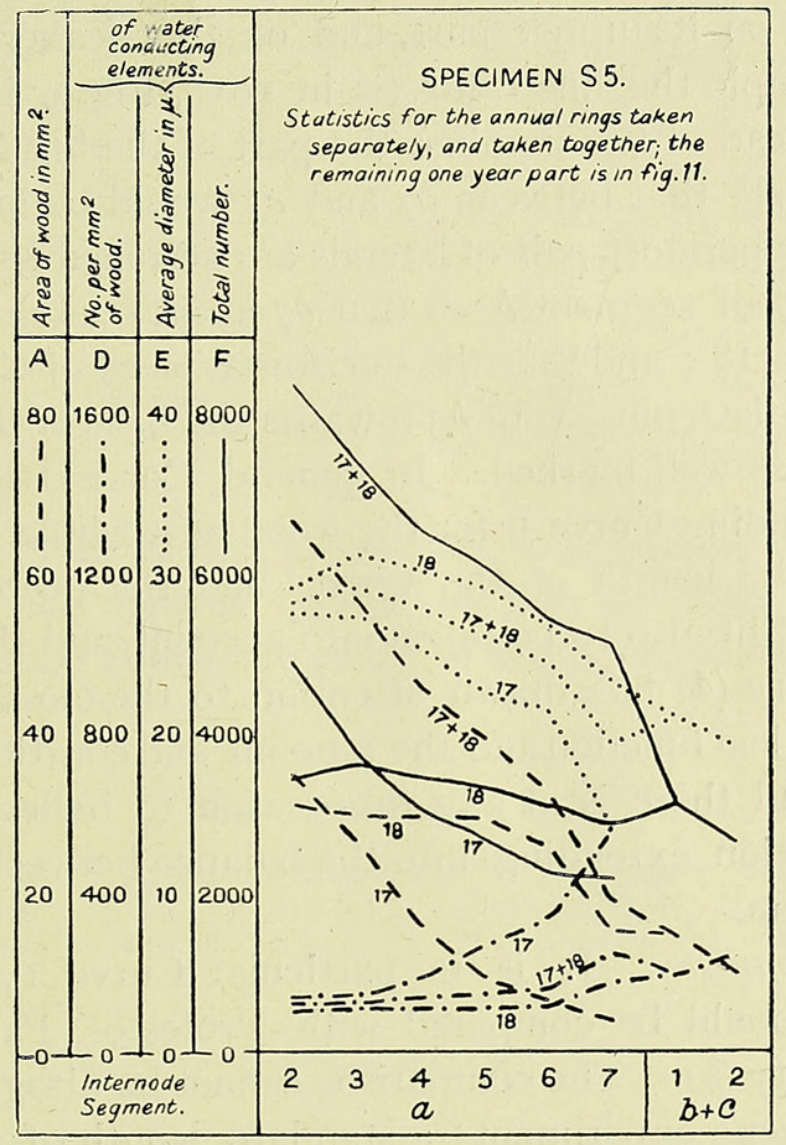

FIG. I3.

spicuous irregularities are local maxima at the ends of the segments. In some cases these are sufficient to eliminate the effect of the maxima at the beginnings of the segments, which appear in Curves $\mathrm{F}$ for the annual rings taken separately, as pointed out in Fig. 4 ; examination of Figs. 3 and 10 will serve to illustrate this point. At the end internodes, naturally, $\mathrm{F}$ includes many very small elements, as is indicated by the local minima in Curves $\mathrm{E}$, Figs. 3, 7, and Io; consequently in Curves B, Figs. 2, 6, and 9, which give the result of taking these two factors together, there is less irregularity. If Curve $\mathrm{B}$ be taken to express as far as possible the absolute conductivity of the wood as a whole, its general slope downwards from base to apex of the plant may be considered with reference to the number of leaves borne 
on the plant. As explained above, it is only in the final segment of the line that the number of leaves supplied decreases regularly in correspondence with equal intervals on the base line; consequently it is to be expected that in passing through the remaining segments Curve $B$ will show less regularity. In Figs. 2, 6, 9, and $\mathrm{I} 2$, an attempt is made to correlate the shape of Curve B with the number of leaves supplied, as represented by the line G. It is necessary, of course, to fix an arbitrary vertical scale for G, as data for the actual areas of the leaf surfaces are not available. The line should be examined in connexion with Fig. I. From observations on plants in leaf, it is clear that the leaves on the lower part of the leader are larger than those on its upper part, and on the weaker branches. Thus, taking as an example the line G for $\mathrm{S}_{4}$ in $\mathrm{I}_{918} 8$, Fig. 9 , if G were to represent leaf area instead of leaf number, the part of the line between $a_{3}$ and $b 6$ would be lower and that between $b_{7}$ and $c_{5}$ would be higher. It is to be noticed that the uppermost pair of laterals are attached to the node between internodes 6 and 7 of segment $b$, so that $b 7$ and $c$ I serve the same number of leaves during I $9 \mathrm{I} 8$; and that the horizontal piece of Curve $\mathrm{G}$ is reflected in Curve B. The flattening from $b_{3}$ towards the base of the plant is evident in Curve B, but less well marked. In general, Curve G seems to agree best with the corresponding Curve B for the wood as a whole. Of course, other factors, such as the length of the vessels and the proportion of wide to narrow vessels, ought also to be taken into account, and this might alter the relation. Salisbury (4) has drawn attention to the close correlation so far observed between leaf function and the amount and constitution of the xylem in the petiole, and there is at any rate reason to believe in the existence of such a correlation extending into the balance between the annual rings of wood in the stem.

General comparison. It is in particular Curve C, for the wood as a whole, which should be compared with Professor Farmer's figures for specific conductivity (5). The comparison cannot be altogether satisfactory ; in Professor Farmer's experiments a standard length of shoot, $\mathrm{I}_{5} \mathrm{~cm}$., was used, regardless of the number of nodes; and the specific conductivity was worked out on the basis of the area of the transverse section of the wood at the middle of this length. In the present paper, length is disregarded in favour of the number of internodes, that is, the number of leaves supplied ; and it is shown that there is a considerable variation in the value arrived at for specific conductivity at different parts of the same shoot, and within a length of $15 \mathrm{~cm}$. This variation, again, applies only to values for internodes, and neglects conditions occurring at the nodes, while it takes into account only the transverse aspect. Thus it is difficult, from the figures obtained in this inquiry, to make general averages, which will be comparable with Professor Farmer's figures. An average can be obtained for each shoot at the end of each year, from the values of $\mathrm{C}$ for every internode along 
the shoot, and this is the information given in the following table, which includes also corrected figures for the Hazel and Ash shoots on the same basis. In this way, however, the shorter internodes have more weight in determining the averages, when compared with averages taken from values for equal lengths. From such considerations it is evident that no very close correlation can be expected between the two sets of figures.

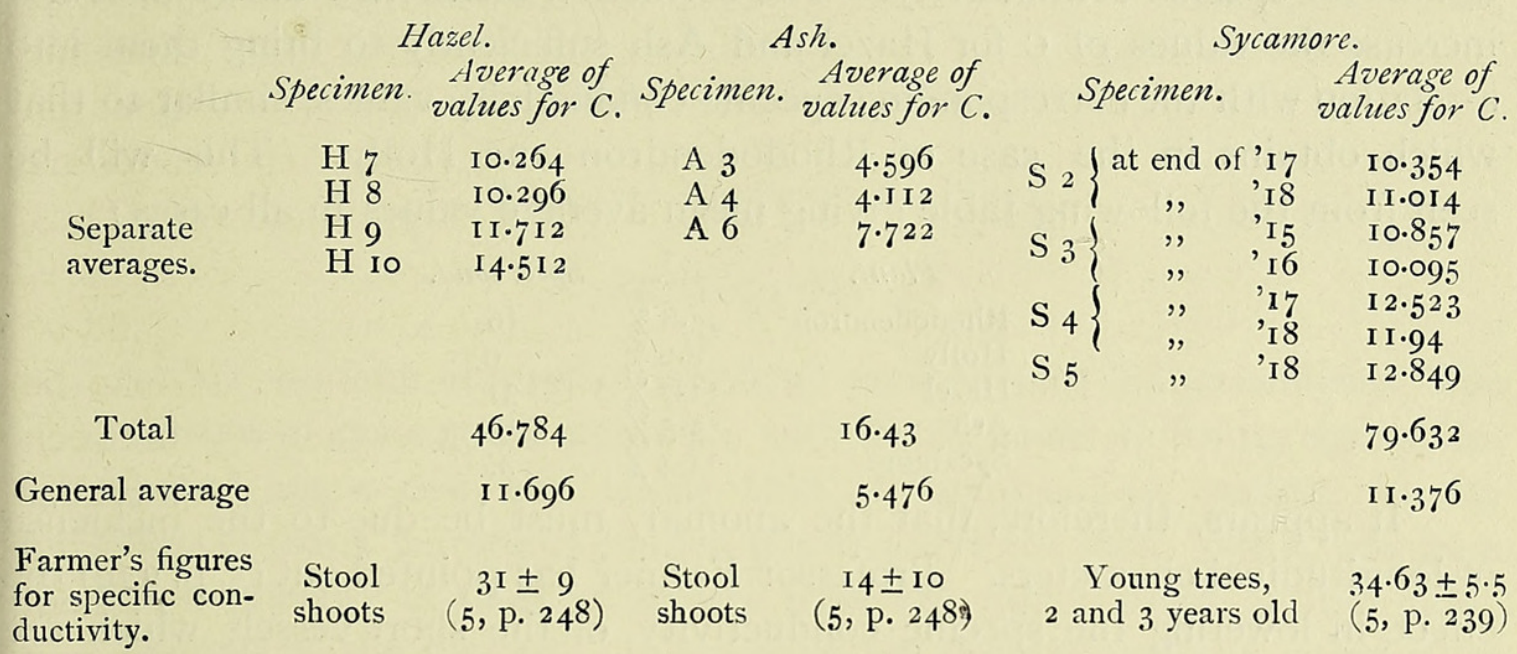

The averages given in the above table were selected to give the fairest comparison with the figures quoted in the last line. The remaining averages, not included above, are given in the table which follows:

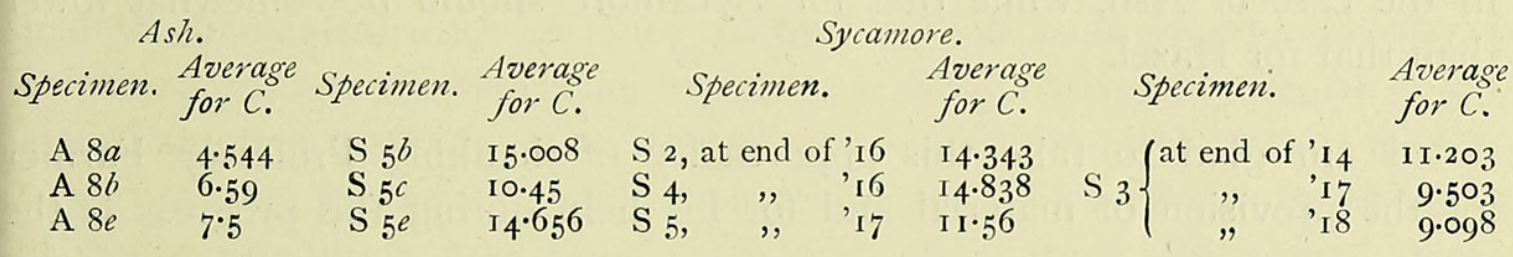

\section{SUMMARY.}

In this paper are described the results of an investigation into the constitution of the wood of young Sycamore plants, with special reference to its efficiency for the conduction of water. The work is a continuation of that begun on stool shoots of Hazel and Ash, but the observations are not confined to first-year wood. The writer takes this opportunity of correcting a mistake which appears in some of the figures given in the earlier papers. With regard to wood of the second and outer annual rings, it is pointed out that there is less variation in the specific conductivity for water than in the first-year wood; the vessels are wider, but less abundant, and this tends to make the figures for specific conductivity become somewhat lower. In general the specific conductivity in the wood of young Sycamore plants, estimated in its transverse aspect, is near that found for Hazel stool shoots, and higher than that for Ash. 


\section{Note.}

Miss Rivett has been so good as to let me see a copy of her paper (8) on Rhododendron and Holly, before its publication. On p. 549 she draws attention to the lack of consistency between the deciduous and evergreen woods investigated, in comparing the data for $\mathrm{C}$ with Professor Farmer's figures for specific conductivity. The correction mentioned above does not increase the values of $\mathrm{C}$ for Hazel and Ash sufficiently to bring them into a relation with the corresponding specific conductivity values, similar to that which obtains in the case of Rhododendron and Holly. This will be seen from the following table giving mean average values in all cases :

$\begin{array}{lrc}\quad \text { Plant. } & C . & \text { Spec. cond. } \\ \text { Rhododendron } & 23.8 \% & \mathrm{I} 6 \\ \text { Holly } & 8.0 \% & 9 \\ \text { Hazel } & \mathrm{II} \cdot 7 \% & 3 \mathrm{I} \\ \text { Ash } & 5.5 \% & \mathrm{I}^{\circ} \\ \text { Sycamore } & 11.4 \% & 35\end{array}$

It appears, therefore, that the anomaly must be due to the incidence of longitudinal characters. Professor Farmer has pointed out (5, p. 249) the effect, in lowering the specific conductivity, of the short vessels which are characteristic of the evergreens. Miss Rivett concludes that the narrower and probably shorter vessels in the evergreens offer more resistance to the passage of water, so that for them a comparatively high value for $\mathrm{C}$ is to be expected. In this sense a particularly low value for $\mathrm{C}$ should be found in the case of Ash, while that for Sycamore should be somewhat lower than that for Hazel.

I am glad to take this opportunity of thanking Professor Farmer for the provision of material and for his help during the progress of the work.

\section{LITERATURE CITED.}

1. Strasburger: Ueber den Bau und die Verrichtungen der Leitungsbahnen in den Pflanzen. I89I.

2. Solereder : Systematische Anatomie der Dicotyledonen. 1899.

3. HaberlandT : Physiological Plant Anatomy; translation by Drummond from edition of 1909 . I9I4.

4. Salisbury, E. J. : The Determining Factors in Petiolar Structure. New Phyt., vol. xii, I9I3.

5. Farmer, J. B.: On the Quantitative Differences in the Water-conductivity of the Wood in Trees and Shrubs, Parts I and II. Proc. Roy๋. Soc., B., vol. xc, I91 8.

6. Holmes, M. G.: A Study in the Anatomy of Hazel-wood with reference to Conductivity of Water. Ann. Bot., vol. xxxii, I9I8.

7. : Observations on the Anatomy of Ash-wood with reference to Water-conductivity. Ibid., vol. xxxiii, I9I9.

8. RivetT, M. F. : The Anatomy of Rhododendron ponticum, L., and of Ilex Aquifolium, L., in reference to Specific Conductivity. Ibid., vol. xxxiv, 1920. 


\section{$2 \mathrm{BHL}$ Biodiversity Heritage Library}

Holmes, M. G. 1921. "A contribution to the study of water-conductivity in sycamore wood." Annals of botany 35, 251-268.

https://doi.org/10.1093/oxfordjournals.aob.a089756.

View This Item Online: https://www.biodiversitylibrary.org/item/235780

DOI: https://doi.org/10.1093/oxfordjournals.aob.a089756

Permalink: https://www.biodiversitylibrary.org/partpdf/319001

\section{Holding Institution}

Smithsonian Libraries

\section{Sponsored by}

Biodiversity Heritage Library

\section{Copyright \& Reuse}

Copyright Status: Not in copyright. The BHL knows of no copyright restrictions on this item.

This document was created from content at the Biodiversity Heritage Library, the world's largest open access digital library for biodiversity literature and archives. Visit BHL at https://www.biodiversitylibrary.org. 